\title{
Application of cell immobilization technology to promote nitritation: A review
}

\author{
Pattaraporn Kunapongkiti ${ }^{1}$, Chaiwat Rongsayamanont ${ }^{2}$, Panida Nayramitsattha ${ }^{1}$, Tawan Limpiyakorn ${ }^{1,3,4^{+}}$ \\ ${ }^{1}$ Department of Environmental Engineering, Faculty of Engineering, Chulalongkorn University, Bangkok 10330, Thailand \\ ${ }^{2}$ Environmental Assessment and Technology for Hazardous Waste Management Research Center, Faculty of Environmental Management, Prince of \\ Songkla University, Songkhla 90110, Thailand \\ ${ }^{3}$ Research Network of NANOTEC-CU on Environment, Department of Environmental Engineering, Faculty of Engineering, Chulalongkorn University, \\ Bangkok 10330, Thailand \\ ${ }^{4}$ Biotechnology for Wastewater Engineering Research Group, Chulalongkorn University, Bangkok 10330, Thailand
}

\begin{abstract}
Nitritation, the oxidation of ammonia to nitrite without subsequent oxidation to nitrate, is a starting step for nitrite-based nitrogen removal approaches. This process can be induced by maintaining specific operating conditions that facilitate ammonia oxidation but deteriorate nitrite oxidation. In recent years, a number of publications have demonstrated the ability of cell immobilization to maintain nitritation and an oxygen-limiting strategy was suggested to be a key to the success of the approach. However, several aspects related to the success and failure of such systems remains unclear and requires further in-depth clarification. This review provides current information on the utilization of cell immobilization in nitritation reactors. Common operating strategies that promote nitritation by controlling environmental conditions are summarized in the first part of the review. The application of cell immobilization, including cell attachment, cell granulation, and cell entrapment systems, as well as microenvironments, and microbial distributions within cell immobilization matrices, are elaborated in the middle part of the review. Problems encountered in the operation of nitritation reactors using cell immobilization are discussed as opportunities for further research at the end of the review.
\end{abstract}

Keywords: Ammonia oxidation, Cell entrapment, Nitritation, Nitrite oxidation, Novel nitrogen removal

\section{Introduction}

Nitrogen can be removed from wastewater by transforming active nitrogen species (ammonia, nitrite, and nitrate) into an inactive species (nitrogen gas), which is promptly released into the atmosphere (Fig. 1). Conventional nitrogen removal relies on nitrification and denitrification processes that are generated under aerobic and anoxic conditions, respectively. In nitrification, the oxidation of ammonia to nitrite is performed by ammonia-oxidizing microorganisms. Subsequently, nitrite-oxidizing microorganisms oxidize nitrite into nitrate. In denitrification, heterotrophic denitrifying microorganisms reduce nitrate to nitrogen gas by using organic matter as an electron donor, while nitrite, nitric oxide (NO), and nitrous oxide $\left(\mathrm{N}_{2} \mathrm{O}\right)$ are produced as intermediates [1]. In recent times, novel nitrogen removal has become increasingly popular because it provides several advantages over conventional nitrogen removal.
Novel nitrogen removal relies on the oxidation of ammonia to nitrite (nitritation), which is further reduced to nitrogen gas via denitritation (nitrite denitrification) or anaerobic ammonia oxidation (ANAMMOX) (Fig. 1). This process reduces the amount of oxygen required by eliminating the oxidation of nitrite to nitrate, and the amount of organic matter required for the reduction of nitrate to nitrite.

An underlying principle of nitritation is to maintain the activity of ammonia-oxidizing microorganisms, while suppressing the activity of nitrite-oxidizing microorganisms. Promoting oxygen-limited, temperature-elevated, or/and $\mathrm{pH}$-raised conditions are common operating strategies that allow for nitritation in reactors [2-6]. In recent years, ultrasound treatment has been introduced to accomplish nitritation in some studies [7, 8]. Cell immobilization, including cell attachment, cell granulation, and cell entrapment, has recently been employed to facilitate nitritation in reactors [9-12]. With the
This is an Open Access article distributed under the terms of the Creative Commons Attribution Non-Commercial License (http://creativecommons.org/licenses/by-nc/3.0/) which permits unrestricted non-commercial use, distribution, and reproduction in any medium, provided the original work is properly cited.
Received April 15, 2019 Accepted December 01, 2019

${ }^{\dagger}$ Corresponding author

Email: tawan.1@chula.ac.th

Tel: +66-2-218-6667 Fax: +66-2-218-6666 


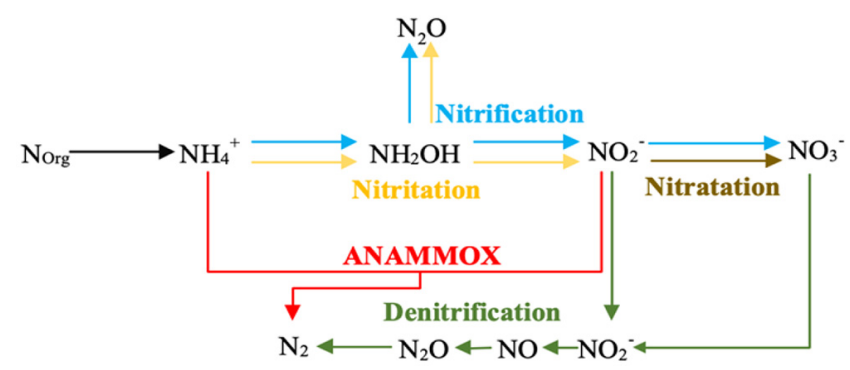

Fig. 1. General processes for nitrogen removal in wastewater treatment systems modified from Thamdrup [98].

assistance of cell immobilization, an oxygen concentration gradient can be formed along the depth of cell immobilization matrices, leading to the creation of an oxygen-limiting zone within the matrices that facilitates nitritation [13-15]. However, the application of cell immobilization for nitritation has so far only been carried out in limited study conditions, and thus expanded clarification is still required for real-world application. In addition, in-depth information regarding microenvironments, microbial distribution, and microbial activity within the cell immobilization matrices have not been well-described, information that is crucial in understanding how to improve system performance. This review provides current advancements in using cell immobilization to drive nitritation. The review is divided into 3 main parts: 1) general information required for operating nitritation reactors, 2) application of cell immobilization to promote nitritation, as well as microenvironments and microorganisms-related aspects within the cell immobilization matrices, and 3) problems encountered in the operation of nitritation reactors using cell immobilization.

\section{Microorganisms Involved in Ammonia and Nitrite Oxidation}

Currently, two groups of microorganisms, ammonia-oxidizing bacteria (AOB) and ammonia-oxidizing archaea (AOA), are known to be capable of oxidizing ammonia to nitrite. AOB belong to two sub-phyla, $\gamma$-Proteobacteria and $\beta$-Proteobacteria. $\gamma$-AOB are, for example, Nitrosococcus oceani, while $\beta$-AOB are classified into several clusters, including the Nitrosospira cluster, Nitrosomonas europaea-Nitrosococcus mobilis cluster, Nitrosomonas communis cluster, Nitrosomonas oligotropha cluster, Nitrosomonas marina cluster, Nitrosomonas cryotolerans cluster, and Nitrosomonas Nm143 cluster [16]. Members of the Nitrosospira cluster, Nitrosomonas europaea-Nitrosococcus mobilis cluster, and Nitrosomonas oligotropha cluster are commonly found in wastewater treatment systems [16, 17]. AOA's potential involvement in ammonia oxidation in the global nitrogen cycle was demonstrated in more recent studies [18, 19]. AOA are classified into a newly founded phylum, Thaumarchaeota [20]. AOA have been found to be dominant in some wastewater treatment systems [21, 22], but this is not always the case as AOB rather than AOA were identified as the main ammonia oxidizers in many more wastewater treatment systems [23, 24].

Nitrite-oxidizing bacteria (NOB) that have appeared in wastewater treatment systems include Nitrobacter ( $\alpha$-Proteobacteria), Nitrospira (Nitrospirae), and Nitrotoga ( $\beta$-Proteobacteria) [25-27]. Nitrotoga are found in cold environments, while Nitrobacter and Nitrospira are usually present in mesophilic conditions [28]. Comparing Nitrobacter and Nitrospira, Nitrobacter have a lower affinity to nitrite than Nitrospira; thus, Nitrobacter are commonly found in high-nitrite environments, while Nitrospira can be found in environments low in nitrite concentrations [28].

In recent years, complete ammonia oxidizers (comammox) have been discovered in aquaculture and full-scale wastewater treatment and drinking water treatment systems [29-32]. These microorganisms can convert ammonia to nitrate in a single microorganism. Examples of comammox include some members within Nitrospira [29-32]. So far, the contribution of comammox to ammonia and nitrite oxidation in nitritation reactors has not been well described. A recent study demonstrated that comammox was an abundant ammonia oxidizer and may play an important role in ammonia oxidation in low DO environments similar to those found in nitritation-ANAMMOX reactors [33].

\section{Operating Strategies for Nitritation}

Due to the differences in physiological properties between AOB and NOB, controlling certain environmental parameters, such as temperature, $\mathrm{pH}$, and dissolved oxygen concentration, can lead to the suppression of $\mathrm{NOB}$ activity while allowing AOB activity to proceed [5, 34]. Detailed information on these operating strategies can be found in previous review articles [5, 35, 36]. In recent years, ultrasound treatment has been employed to promote nitritation in reactors $[7,8]$.

Nitritation can be achieved by operating a system at temperatures higher than $35^{\circ} \mathrm{C}$. At $35^{\circ} \mathrm{C}$, the AOB growth rate is twice that of NOB [3]. The SHARON ${ }^{\circledR}$ (Single-reactor system for High Ammonium Removal Over Nitrite) process is an example of a system configuration using a temperature of $30-40^{\circ} \mathrm{C}$ as a strategy to promote nitritation [3]. This operating strategy is suitable for treatment of sidestream wastewater, as the temperature of anaerobic digester effluent is around the temperature ranges that promote nitritation. Therefore, no or little energy input is required for nitritation of sidestream wastewater. On the other hand, this operating condition is hardly to be maintained for mainstream treatment due to the temperature gap between mainstream wastewater temperature $\left(10-25^{\circ} \mathrm{C}\right)$ and the temperature for nitritation $\left(30-40^{\circ} \mathrm{C}\right)$.

Both AOB and NOB activity can be inhibited by high free ammonia (FA) and free nitrous acid (FNA) concentrations. However, AOB are more tolerant to FA and FNA concentrations than NOB [2]. Therefore, at a suitable level of FA or FNA, AOB activity proceeds, while NOB activity is inhibited. In suspended-cell systems, FA concentrations of $0.1-4.0 \mathrm{mg} \mathrm{L}^{-1}$ and FNA concentrations of $0.24 \mathrm{mg} \mathrm{L}^{-1}$ were found to inhibit nitrite oxidation [2, 37, 38], while ammonia oxidation were not inhibited until higher levels of FA (10-150 mg L $\left.{ }^{-1}\right)$ and FNA $(1.35 \mathrm{mg}$ $\left.\mathrm{L}^{-1}\right)[2,38]$. In context of using $\mathrm{pH}$ condition to influence ni- 
tritation, Sinha and Annachhatre [5] suggested that nitrite accumulation increased when $\mathrm{pH}$ was controlled to higher values. High FA condition can be easily maintained when handling particular types of wastewater that contain high ammonia content, such as sidestream wastewater and effluents from anaerobic reactors treating leachate and animal manures. For municipal wastewater, promoting FA inhibition is likely impractical as a result of less available ammonia in the wastewater; therefore, FNA inhibition is rather a better option [39]. During mainstream treatment, NOB inhibition by FNA can be promoted via inline sludge treatment with FNA-concentrated solution ie., an effluent of partial nitrified-sidestream treatment unit [38].

Oxygen-limiting conditions have been employed to promote nitritation in laboratory- and full-scale reactors [6, 11, 40]. The strategy is based on the difference in oxygen affinity between $\mathrm{AOB}$ and NOB. The half-saturation coefficient for oxygen $\left(K_{0}\right)$ of NOB is higher than that of AOB. The $K_{O}$ of AOB is in the range of $0.03-0.99 \mathrm{mg} \mathrm{L}^{-1}$, while the $K_{O}$ for NOB ranges from 0.4 to $1.4 \mathrm{mg} \mathrm{L}^{-1}[4,6]$. Therefore, under oxygen-limiting conditions, the AOB growth rate becomes higher than the NOB growth rate, which helps create nitritation in reactors. Hanaki et al. [41] demonstrated that operating laboratory-scale mixed-flow reactors at a dissolved oxygen (DO) concentration of $0.5 \mathrm{mg} \mathrm{L}^{-1}$ $\left(25^{\circ} \mathrm{C}\right)$ could inhibit nitrite oxidation and not ammonia oxidation. Maintaining oxygen-limiting condition requires no additional energy or chemical; therefore, this operating strategy has been widely used for treatment of both high and low ammonia content wastewater [39]. However, some recent studies have shown a failure of nitritation during long term operation of reactors employing oxygen-limiting condition as the operating strategy [42-43], which could be caused by the adaptation of some NOB groups to the oxygen-limiting environment. This point will be further discussed in section 7.1.

Low-frequency and low-density ultrasound has been applied to increase AOB and decrease NOB activity [7, 8]. Zheng et al. [7] indicated that ultrasound at a frequency of $40 \mathrm{kHz}$ and a density of $0.027 \mathrm{~W} \mathrm{mL^{-1 }}$ for $2 \mathrm{~h}$ of irradiation time improved AOB activity while inhibiting NOB activity. During ultrasound treatment, ultrasound generated shock waves and cell walls burst to increase temperature and $\mathrm{pH}$ [7]; temperature in the tests reached up to $35.1^{\circ} \mathrm{C}$ and the $\mathrm{pH}$ increased up to 8.5, both optimums for nitritation. Zheng et al. [8] claimed that ultrasound treatment was easier to operate and made maintaining nitritation easier than other methods.

\section{Nitritation by Cell Immobilization}

Cell immobilization allows microorganisms to grow and perform activity in/on a solid matrix. Cell immobilization helps enhance cell residence time, substrate loading rate, cell-liquid separation, and cell protection from environmental stress. Cell immobilization can be carried out by several approaches, including cell attachment, cell granulation, and cell entrapment [44]. Cell attachment is the formation of biofilms on the internal and external surfaces of supporting materials. Cell granulation is the self-aggregation of microorganisms into granule-like aggregates. Cell entrapment is the en- trapment of cells into proper supporting matrices.

With cell immobilization, an oxygen concentration gradient is created along the depth of a biofilm, granule, or entrapped-cell matrix [13, 45], leading to the creation of an oxygen-limiting zone somewhere inside the matrix to facilitate nitritation [15]. Therefore, DO concentrations in the bulk solution can be maintained at low ranges but do not need to reach oxygen-limiting levels as required for suspended cell systems, allowing higher flexibility of the operation ranges to maintain nitritation in the reactors [11]. Fig. 2 shows bulk DO concentrations applied for nitritation in suspended-cell and cell immobilization systems. It is noted that other parameters than the bulk DO concentrations also differ among the studies in Fig. 2. However, with neglecting those parameters, optimal DO concentrations in the bulk solution for nitritation in suspended-cell systems are in the range of $0.5-2.0 \mathrm{mg} \mathrm{L}^{-1}$. However, a wider range of bulk DO concentrations $\left(0.3-3.0 \mathrm{mg} \mathrm{L}^{-1}\right.$ in most studies) is allowed in cell immobilization systems to maintain nitritation. This flexibility of cell immobilization systems over suspended-cell systems is probably a result of the cell immobilization matrices' ability to protect the cells from a higher range of bulk DO concentrations while creating the oxygen-limiting zones inside the matrices to promote nitritation.

Table 1 shows the application of cell immobilization, including cell attachment (biofilm), cell granulation (aerobic granule), and cell entrapment (entrapped cell), for nitritation reactors. Regarding the cell attachment system, studies have demonstrated that nitritation was achieved using a variety of reactor configurations, with examples including continuous moving bed biofilm reactors, sequencing batch biofilm reactors, and continuous-flow hybrid shortcut biological nitrogen removal [46-48]. DO concentrations in the bulk solution were maintained in a range of 0.3-6.4 $\mathrm{mg} \mathrm{L}^{-1}$, while water temperature and $\mathrm{pH}$ were controlled in ranges that did not facilitate nitritation $\left(6-26^{\circ} \mathrm{C}\right.$ and $7.3-8$, respectively) (Table 1). This suggests that biofilm formation helps facilitate nitritation, although the oxygen concentrations in the bulk sol

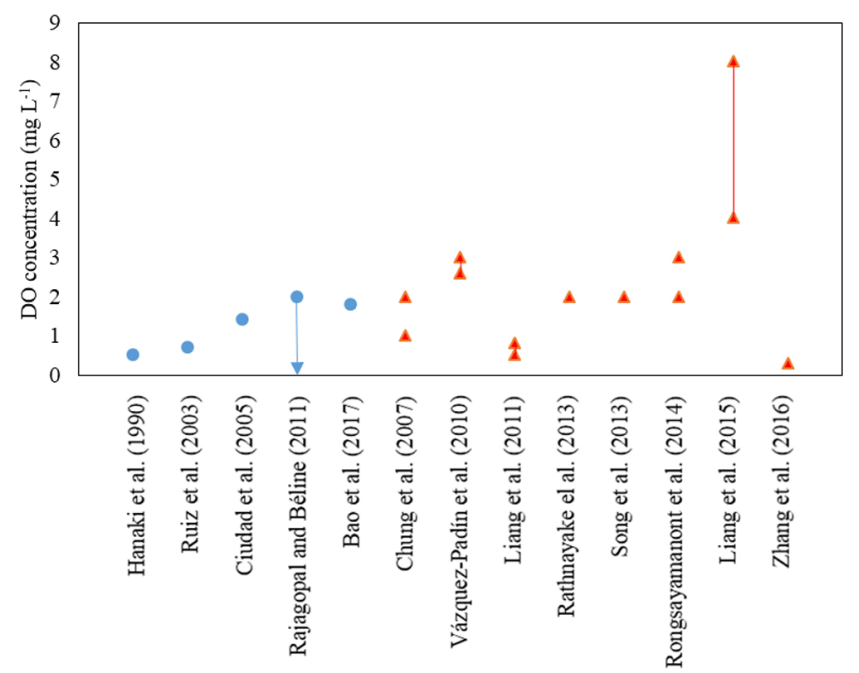

Fig. 2. Dissolved oxygen concentrations in bulk solutions for maintaining nitritation in suspended-cell (circle) and cell immobilization (triangle) systems [11, 13, 14, 41, 46, 47, 49, 99-104]. 


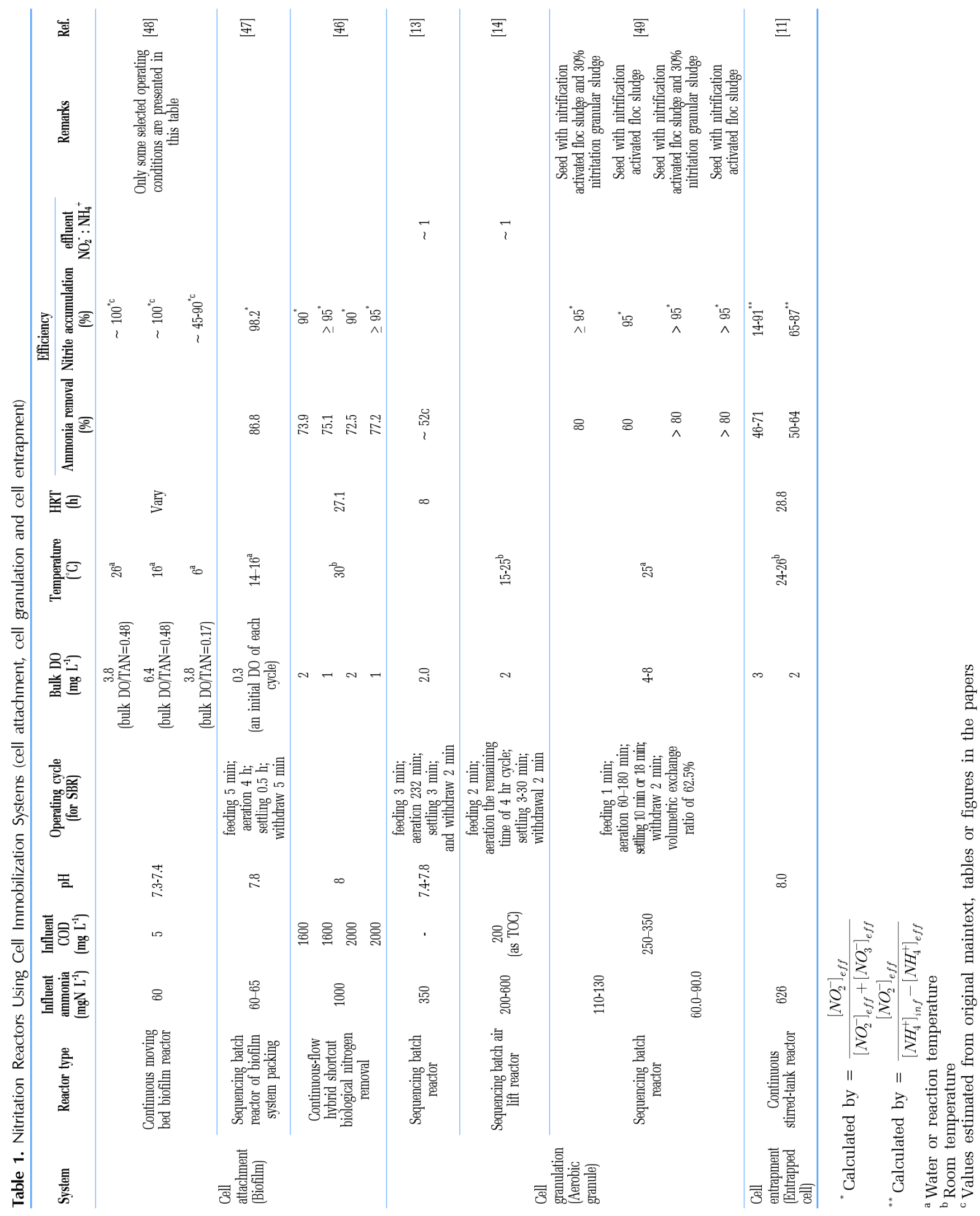


ution did not reach oxygen-limiting levels in some studies. Zhang et al. [47] compared the sustainability of maintaining nitritation in an activated sludge process and a biofilm system [47]. Their study showed that nitritation was sustained in the biofilm system with nitrite accumulation up to $98.2 \%$, while in the activated sludge process only up to $90.1 \%$. The cell attachment system was found to be able to maintain long-run nitritation performance in reactors. Furthermore, Chung et al. [46] demonstrated that nitritation could be maintained for over 1.5 years in a hybrid suspended-, attached-growth system carrying polyvinyl alcohol (PVA) sponges.

For cell granulation, aerobic granules have been successfully introduced to promote nitritation in sequencing batch reactors [13, 14, 49]. Rathnayake et al. [13] and Song et al. [14] were able to generate an approximately 1:1 $\mathrm{NO}_{2}{ }^{-} / \mathrm{NH}_{4}{ }^{+}$effluent by cell granulation. It was demonstrated that a granular sludge reactor can be started up more rapidly by using seeds mixed with nitrifying floccular sludge and 30\% partial nitrifying granular sludge than by using seeds prepared from nitrifying floccular sludge alone [49].

Cell entrapment can also achieve nitritation by immobilizing cells within gel matrices. With this idea, entrapped cells have been applied to nitritation reactors [9, 11, 12, 50, 51]. The gel matrix to entrap cells can be made by a variety of polymeric materials, such as calcium alginate, sodium alginate, PVA, PVA/alginate, and polyethylene glycol (PEG) [9, 11, 12, 50-52]. It is shown that nitrifiers entrapped in PVA/alginate gel beads promoted the build-up of nitrite in the reactor [12]. The immobilization of nitrifiers and co-immobilization of nitrifiers and denitrifiers in calcium alginate gel beads have also achieved nitritation [9]. DO concentrations in bulk solution at 2 and $3 \mathrm{mg} \mathrm{L}^{-1}$ were reported to be low enough to promote nitritation using PVA gel matrices [11]. At this DO ranges, the preparation of a suspended inoculum with the ability to partial nitrify was not needed during the production of entrapped cells. With the assistance of cell entrapment, all suspended inocula with non-nitrifying, nitrifying, and partial nitrifying activity can reach nitritation within similar periods of operation [11].

The operating conditions required for nitritation in cell immobilization reactors can be different from those in suspended-cell reactors because substrate transfer from the bulk solution to microorganism cells is impacted by cell immobilization matrices. Several approaches of cell immobilization have been employed to promote nitritation in reactors. However, the characteristics of cell immobilization matrices are distinct depending on the type of approach. Specific operating conditions to attain nitritation are required for a particular type of cell immobilization system and need to be customized.

\section{Microenvironments and Microorganisms- Related Aspects within the Cell Immobilization Matrices}

Although cell immobilization has successfully been applied to promote nitritation, microenvironments inside cell immobilization matrices have not yet been clearly observed. Information related to in-situ oxygen concentration gradients inside cell immobilization matrices in nitritation reactors was provided only in some studies (Table 2). In biofilm, oxygen can penetrate up to approximately $600-650 \mu \mathrm{m}$ from the surface of the biofilm [45]; this value was around 100-300 and 120-320 $\mu \mathrm{m}$ for aerobic granules and entrapped cell matrices [13-15, 53]. With the formation of an oxygen concentration gradient, an oxygen-limiting zone can be found within the cell immobilization matrices. For example, a zone with a DO range of $0.5-1.5 \mathrm{mg} \mathrm{L}^{-1}$ occurred at depths of $10-230 \mathrm{~mm}$ from the surface of the entrapped cells. It is suggested that this zone with the oxygen-limiting environment facilitated nitritation by inhibiting NOB activity [15]. Oxygen concentration gradients can be created inside cell immobilization matrices as a result of 1) the obstruction of oxygen transfer by materials used for cell immobilization, as well as microbial products and inert solids that are trapped within the cell immobilization matrices, and 2) the utilization of oxygen by aerobic microorganisms distributed throughout the cell immobilization matrices $[54,55]$. Aerobic microorganisms are the microorganisms that play the main role in utilizing oxygen in cell immobilization matrices. These microorganisms help create an oxygen concentration gradient in cell immobilization matrices; in the meantime, their appearance in cell immobilization matrices is influenced by the oxygen concentrations inside the matrices.

For combined carbon oxidation and nitrification systems, heterotrophic microorganisms are distributed around the surface of cell immobilization matrices as a result of their lower affinity to oxygen and higher growth rate than autotrophic nitrifying microorganisms. Autotrophic nitrifying microorganisms are located in the deeper parts of cell immobilization matrices [56]. Among autotrophic nitrifying microorganisms, AOB and NOB share spaces in biofilm matrices [57]. Okabe et al. [57] demonstrated that AOB were distributed throughout biofilm matrices where ammonia was reduced to nitrite, while NOB appeared in the inner part of the matrices where nitrite was oxidized to nitrate.

For a nitritation system, AOB occurred on the outer layers of aerobic granules in a laboratory-scale granular sludge reactor without organic carbon feeding [13]. AOB was spatially distributed

Table 2. Distances of Oxygen Penetration from Surface of Cell Immobilization Matrices

\begin{tabular}{|c|c|c|c|c|}
\hline System & $\begin{array}{c}\text { DO in bulk solution } \\
\left(\mathrm{mg} \mathrm{L}^{-1}\right)\end{array}$ & $\begin{array}{l}\text { Distance of oxygen penetration } \\
\text { from surface }(\mu \mathrm{m})\end{array}$ & Remarks & Reference \\
\hline Biofilm & $\sim 0.2-0.4^{*}$ & $\sim 600-650$ & & {$[45]$} \\
\hline \multirow{3}{*}{ Aerobic granule } & 2 & $\sim 300$ & Granule diameter $=2 \mathrm{~mm}$ & {$[13]$} \\
\hline & 2.5 and 7 & $\sim 100^{*}$ & Granule diameter $=2-3 \mathrm{~mm}$ & [14] \\
\hline & 2 and 4 & $\sim 200$ & & {$[53]$} \\
\hline Entrapped cell & $\sim 1.9$ & $120-320$ & & [15] \\
\hline
\end{tabular}

*Values estimated from original figures in the papers 
at less than $300 \mu \mathrm{m}$ from the aerobic granule surface [13, 14, 53]. For entrapped-cell-based reactors, AOB occurred near the surface of gel bead matrices at approximately $100 \mu \mathrm{m}$ from the surface and NOB was found at a similar location [10, 11]. The localization of AOB aggregates within entrapped cell matrices was found to be related to the microenvironment that serves their growth. For example, strong signals of $\mathrm{AOB}$ cells, as observed by fluorescence in situ hybridization (FISH), arose within $50 \mu \mathrm{m}$ from the gel bead surface where the DO concentrations were at $0.5-1.5 \mathrm{mg}$ $\mathrm{L}^{-1}$, the range that promote AOB but inhibit NOB [15].

Different types of cell immobilization matrices create distinct patterns of microenvironments distributed within the matrices [13-15, 45, 53]. The formation of an oxygen concentration gradient is dependent on not only the characteristics of matrix materials, but also the activity of aerobic microorganisms that are involved in chemical utilization in reactors. This provides different niche microenvironments that support or inhibit specific groups of microorganisms in the cell immobilization matrices. Interrelation between groups of microorganisms and microenvironments is worth further study, as a better understanding of how different types of cell immobilization assist the promotion of nitritation can help improve system performances.

\section{Incorporation of Nitritation to Novel Nitrogen}

\section{Removal Process}

\subsection{Nitritation-Heterotrophic Denitritation Process}

During the nitritation-heterotrophic denitritation process, both autotrophic nitrite oxidation and heterotrophic nitrate reduction are shortcut. In order to maintain the process, nearly 100\% conversion of ammonia to nitrite has to be obtained, before the subsequent nitrite conversion to nitrogen gas occurs. The nitritation- heterotrophic denitritation process reduces energy expenditure substantially via lowering the need for aeration by $25 \%$ and decreases extra organic matter requirement for denitrification by $40 \%$ [58]. In addition, the cost for sludge disposal is also reduced due to lower excess sludge generation [59]. Maintaining a high level of stability is essential in maintaining an effective nitritation- heterotrophic denitritation process. Jiang et al. [60] applied a combination approach of limiting DO and FNA sludge treatment to achieve nitritation- heterotrophic denitritation in a continuous flow activated sludge treating mainstream municipal wastewater. In their study, more than $78 \%$ of nitrite accumulation was achieved after simultaneously lowering DO to $0.5 \mathrm{mg} \mathrm{L}^{-1}$ and daily exposing $30 \%$ of excess sludge with $1.2 \mathrm{mg} \mathrm{N} \mathrm{L}^{-1}$ FNA for $18 \mathrm{~h}$. Gu et al. [61] reported that $78 \%$ of total nitrogen in mainstream municipal wastewater was removed via the nitritation- heterotrophic denitritation process. Limiting DO to $1.5 \mathrm{mg} \mathrm{L}^{-1}$ at $30^{\circ} \mathrm{C}$ promoted $97 \%$ of nitrite accumulation with an extremely low nitrate concentration ( < $0.5 \mathrm{mg} \mathrm{N} \mathrm{L}^{-1}$ ) in a sequencing batch reactor.

\subsection{Nitritation-ANAMMOX Process}

The combination of nitritation and ANAMMOX process has been considered as the most sustainable and cost-effective nitrogen re- moval approach [59]. In order to complete the process, approximately half of the ammonia nitrogen should be first converted to nitrite nitrogen under aerobic conditions leading to an equal molarity of ammonia and nitrite in the effluent. Subsequently, the remaining ammonia is converted anaerobically to nitrogen gas and a little nitrate by chemoautotrophic ANAMMOX bacteria with nitrite as an electron acceptor [62]. Because only half of the influent ammonia nitrogen is aerobically oxidized to nitrite nitrogen, overall oxygen consumption is reduced by $60 \%$ in the nitritation-ANAMMOX process when compared to the nitrification-denitrification process [1]. Both AOB and ANAMMOX bacteria are slow-growing autotrophs, resulting in low sludge production and no need of additional organic matter for denitrification. Mainstream nitritation-ANAMMOX process was carried out mostly in cell immobilization-based reactors, such as granular sludge and moving bed biofilm reactors in order to maintain an adequately long sludge age for the slow-growing ANAMMOX bacteria [63]. The process which was originally implemented in two separated stages has recently been shifted to a single reactor [64]. Simultaneously suppressing NOB activity and promoting the growth of AOB and ANAMMOX bacteria are the two key challenges for implementing the process in a single reactor [65]. Tao and Hamouda [66] found that by maintaining bulk DO concentration at $1.21 \mathrm{mg} \mathrm{L}^{-1}$, both $\mathrm{AOB}$ and ANAMMOX bacteria can be retained effectively in a moving bed biofilm reactor while NOB growth is largely suppressed. $88.9 \%$ of total nitrogen was removed at a nitrogen loading rate of $1000 \mathrm{~g} \mathrm{~N} \mathrm{~m}^{-3} \mathrm{~d}^{-1}$. Both AOB and NOB were predominantly observed at the top layer of the moving bed biofilm matrix, while ANAMMOX bacteria dominated the middle and bottom layers of the matrix. Liu et al. [67] reported that simultaneous nitritation, ANAMMOX and denitrification occurred in a granular upflow anaerobic sludge blanket reactor for mainstream treatment with $>90 \%$ nitrogen removal at a nitrogen loading rate of $2,280 \mathrm{~g} \mathrm{~N} \mathrm{~m}^{-3} \mathrm{~d}^{-1}$, bulk DO concentration of $0.2-0.4 \mathrm{mg} \mathrm{L}^{-1}$, and temperature of $16^{\circ} \mathrm{C}$.

\section{Problems Encountered in the Operation of Nitritation Reactors Using Cell Immobilization}

\subsection{Insufficient Suppression of NOB Activity Using Oxygen-Limiting Conditions as the Sole Operating Strategy}

Failure to suppress NOB activity has been frequently observed in some circumstances, such as deammonification of mainstream wastewater or long-term operation of nitritation reactors, even though oxygen-limiting conditions were maintained [39]. Several attempts have been made to clarify the potential causes of this failure [68-71]. The existence of conditions leading to NOB proliferation, such as a low free ammonia concentration and low temperature, was identified as the cause of unstable nitritation performance during mainstream deammonification [39]. In addition, it has been found that NOB is adaptive and can survive and perform activity under a microaerobic environment [72, 73].

Oxygen-limiting conditions have been employed to promote ni- 
tritation under the assumption that AOB have a higher affinity to oxygen than NOB [74]. Under this assumption, NOB are considered a single group of microorganisms, although different NOB lineages have distinct growth characteristics and affinity to oxygen [75]. Nitrobacter and Nitrospira are NOB that are commonly found in wastewater treatment systems. The oxygen affinity of these two groups of microorganisms tend to be different, with a lower affinity for Nitrobacter (0.17 - $5.3 \mathrm{mg} \mathrm{L}^{-1}$ ) and a higher affinity for Nitrospira $\left(0.13 \pm 0.06 \mathrm{mg} \mathrm{L}^{-1}\right)$ [76]. Huang et al. [77] reported that Nitrospira was more abundant than Nitrobacter at low DO concentrations $\left(<1.0 \mathrm{mg} \mathrm{L}^{-1}\right)$ in full - scale wastewater treatment plants. Nitrospira can be divided into a few lineages. Nitrospira lineages I and II are usually found in nitrifying wastewater treatment systems. Park and Noguera [78] revealed that Nitrospira lineage I was present in low DO concentrations (0.12 - $\left.0.24 \mathrm{mg} \mathrm{L}^{-1}\right)$. In contrast, Nitrospira lineage II was found in high DO levels $\left(8.5 \mathrm{mg} \mathrm{L}^{-1}\right)$. These indicated that different Nitrospira lineages were adaptive to different DO concentrations. Therefore, some NOB groups could survive and express activity under oxygen - limiting conditions, which likely led to failure of nitritation, especially during long-term operation. A recent study demonstrated an increase in comammox Nitrospira during late operation (from days 200 to 400) of a sequencing batch reactor operated at low DO concentrations [33]. These microorganisms were suggested to potentially play an important role in ammonia oxidation in the nitritation-ANAMMOX-like reactor. The characteristics of NOB should be further explored in cell immobilization matrices. Further works should emphasize the change in NOB communities, especially comammox Nitrospira, toward characteristics of extremely high oxygen affinity within cell immobilization matrices that employ an oxygen-limiting strategy to promote nitritation.

It was recently found that the substrate affinity of $\mathrm{AOB}$ and NOB in cell immobilization matrices is determined predominantly by their own colony sizes rather than their strain-dependent intrinsic affinities [79]. Oxygen affinity of NOB in a given cell immobilization matrix can greatly change over time depending on both the microenvironment and the NOB's adaptation within the matrix. Therefore, it is difficult to permanently repress NOB activity in cell immobilization matrices using an oxygen-affinity-based strategy alone; thus, additional controlling strategies to repress NOB activity should be considered.

Two possible additional strategies are described here. First, controlling the ratio of oxygen to ammonium concentrations has been proven to provide stable NOB repression during long-term operation of a cell immobilization system [80]. When an excess ammonium concentration can be maintained at a given DO concentration, oxygen will be exhausted completely in the AOB-dominant zone located around the outer layer of the cell immobilization matrix. This exhaustion leads to the limitation of oxygen for NOB that surrounds the inner layer of the matrix. In contrast, if a sufficiently high residual ammonium concentration cannot be maintained, the growth and substrate utilization of AOB are limited by ammonia, and oxygen can remain for NOB proliferation. Therefore, strict control of an appropriate ratio between the oxygen and ammonium concentrations is a potential strategy for permanent NOB repression in a cell immobilization system. Poot et al. [81] previously found a short-term effect of the oxygen to ammonium ratio on nitritation in a granular biofilm reactor operated at $20^{\circ} \mathrm{C}$.

Another strategy exploits the synergy between the oxygen-limiting strategy and other strategies. Wang et al. [82] demonstrated that the stability of nitritation was improved during long-term operation by combining FNA inhibition and oxygen-limiting conditions. The authors found that FNA resulted in the washout of Nitrospira due to its strong biocidal effects, while Nitrobacter was eliminated by oxygen-limiting conditions due to its lower oxygen affinity.

\subsection{Nitrous Oxide Production in Nitritation Reactors Operated Using an Oxygen-Limiting Strategy}

$\mathrm{N}_{2} \mathrm{O}$ is a powerful greenhouse gas. Full-scale plants with nitritation and ANAMMOX generate $\mathrm{N}_{2} \mathrm{O}$ at concentrations between 1.2 and $12 \%$ [83]. Nitrification can produce $\mathrm{N}_{2} \mathrm{O}$ via two different pathways: nitrifier nitrification and nitrifier denitrification [40, 84, 85]. With the nitrifier nitrification pathway, $\mathrm{N}_{2} \mathrm{O}$ is produced as a byproduct of the oxidation of hydroxylamine, which is an intermediate in the oxidation of ammonia to nitrite. Terada et al. [83] showed that most $\mathrm{N}_{2} \mathrm{O}$ produced from suspended-growth-based sequencing batch nitritation reactors originated from $\mathrm{AOB}$ via $\mathrm{N}$-nitrosation hybrid $\mathrm{N}_{2} \mathrm{O}$ production, which is driven by the oxidation of hydroxylamine with nitrite as an electron acceptor.

For the nitrifier denitrification pathway, some AOB, such as Nitrosomonas europaea, can switch their activity from nitrification to nitrifier denitrification in an oxygen-limiting environment [84, 86]. $\mathrm{N}_{2} \mathrm{O}$ is produced by $\mathrm{AOB}$ during the reduction of nitrite to nitrogen gas via the activity of AOB-related enzymes including nitrite reductase (catalyzing $\mathrm{NO}_{2}^{-}$reduction to $\mathrm{NO}$ ) and nitric oxide reductase (catalyzing $\mathrm{NO}$ conversion to $\mathrm{N}_{2} \mathrm{O}$ ) [87].

Previous studies have shown that $\mathrm{N}_{2} \mathrm{O}$ production largely depends on several factors, including the concentrations of bulk DO [53], nitrite [88], nitrogen loading rate [89], and organic matter [90]. Peng et al. [91] studied $\mathrm{N}_{2} \mathrm{O}$ production under various DO concentrations ( 0.35 - $\left.3.5 \mathrm{mg} \mathrm{L}^{-1}\right)$ and nitrite in an enriched nitrifying sludge. They found that $\mathrm{N}_{2} \mathrm{O}$ was produced mainly via the nitrifier denitrification pathway in a wide range of $\mathrm{DO}$ and nitrite conditions. Low DO (ca. $<1.5 \mathrm{mg} \mathrm{L}^{-1}$ ) stimulated the nitrifier denitrification pathway at all nitrite levels. While the hydroxylamine oxidation pathway could be the dominant $\mathrm{N}_{2} \mathrm{O}$ production pathway only at a relatively high DO (ca. $3.5 \mathrm{mg} \mathrm{L}^{-1}$ ) and low nitrite (ca. < $10 \mathrm{mg} \mathrm{N} \mathrm{L}^{-1}$ ) levels. Rathnayake et al. [53] observed the effect of DO concentration ( $\left.0.6-2.3 \mathrm{mg} \mathrm{L}^{-1}\right)$ on the production pathway and emission rate of $\mathrm{N}_{2} \mathrm{O}$ in autotrophic partial nitrifying granular sludge. The authors found that $\mathrm{N}_{2} \mathrm{O}$ in granular sludge system was mainly produced via hydroxylamine oxidation by Nitrosomonas europaea on the surface of the oxic layer $(<200 \mu \mathrm{m})$ of the granules. Higher DO activated the ammonia oxidation to hydroxylamine, resulting in stimulating the $\mathrm{N}_{2} \mathrm{O}$ production via the hydroxylamine oxidation pathway. The nitrogen loading rate is known to influence the rate of ammonia oxidation, thus affecting the rates of nitrite accumulation and $\mathrm{N}_{2} \mathrm{O}$ emission in nitrifying biofilm reactors [39]. Recently, Wan et al. [89] found that an increase in nitrogen load $\left(800-2,000 \mathrm{~g} \mathrm{~N} \mathrm{~m}^{-3} \mathrm{~d}^{-1}\right)$ in a combined nitritation-ANAMMOX biofilm accelerated ammonia oxidation and nitrite accumulation, thus promoting $\mathrm{N}_{2} \mathrm{O}$ production (up to $5-6 \%$ of the nitrogen load) via 
nitrifier nitrification. However, the production rate of $\mathrm{N}_{2} \mathrm{O}$ did not increase when the rate of ammonia oxidation and nitrite accumulation became stable.

Although novel nitrogen removal via the nitrite pathway should be implemented to ensure energy savings, the process tends to emit higher $\mathrm{N}_{2} \mathrm{O}$ amounts than conventional nitrogen removal. Therefore, the importance of process optimization needs to be highlighted to minimize this greenhouse gas.

\subsection{Influence of Organic Matter on Nitritation Performance Using an Oxygen-Limiting Strategy}

Organic matter has been found to influence nitritation performance. When organic matter is present over a certain level or at a high loading rate, aerobic heterotrophic microorganisms can rapidly grow and compete with nitrifying bacteria for oxygen. Xu et al. [92] demonstrated that organic matter enhanced nitrite accumulation in nitrifying biofilms because NOB were outcompeted by aerobic heterotrophic microorganisms for oxygen. The study demonstrated that nitritation was achieved with an ammonia removal efficiency of 79 - 95\% and nitrosation (ratio of $\mathrm{NO}_{2}^{-} /\left[\mathrm{NO}_{2}^{-}+\mathrm{NO}_{3}^{-}\right]$) of $80-99 \%$ when the $\mathrm{COD} / \mathrm{N}$ ratio was 2.6. The reactors required a shorter period of time to achieve nitritation than did the reactor with no organic matter supplied. However, an overloading of organic matter can also deteriorate nitritation performance. Rodriguez-Sanchez et al. [93] reported that AOB were outcompeted by aerobic heterotrophic microorganisms for oxygen, which resulted in a decrease in the ammonia-oxidizing activity and relative abundance of $\mathrm{AOB}$ in submerged nitritation biofilters with $0.34 \mathrm{~kg}$ carbon $\mathrm{m}^{-3} \mathrm{~d}^{-1}$. Therefore, at an extremely high organic loading rate, a process unit for the pre-removal of organic matter, such as a high-rate activated sludge [94], a chemically enhanced primary treatment [95], or an anaerobic process [96], is required to lower the amount of organic compounds to improve the stability of nitritation in cell immobilization reactors.

In addition to the competition for oxygen between nitrifying microorganisms and aerobic heterotrophic microorganisms, organic matter can also provide selective pressure to assist the retardation of NOB activity by limiting nitrite for NOB. NOB can be outcompeted for nitrite by heterotrophic denitrifying microorganisms due to the ability of the latter to grow faster when consuming nitrite (specific growth rate: $0.25 \mathrm{~h}^{-1}$ for denitrifiers, 0.02-0.04 $\mathrm{h}^{-1}$ for Nitrospira sp. ; [97]). Wang et al. [97] found that organic matter is critical to suppress NOB and to maintain a stable nitrite accumulation rate in combined nitrifying/denitrifying granular sludge.

\section{Conclusions}

Nitritation can be promoted using cell immobilization. An oxygen concentration gradient is created along the depth of the cell immobilization matrix and an oxygen-limiting zone is generated inside the matrix to facilitate nitritation. Nitritation can be achieved using different cell immobilization approaches, including cell attachment, cell granulation, and cell entrapment. Due to the variation in the characteristics of cell immobilization matrices, microenvironments created within the matrices can be distinct and specific operating conditions may be required for a particular type of the approach. An understanding of the interaction between target microorganisms and microenvironment should be further clarified to improve system operation. Attention should be paid to a few points when operating nitritation reactors using cell immobilization. The adaptive recovery of NOB activity under oxygen stress may occur during long-term operation of cell immobilization reactors. In this case, synergetic operating strategies should be employed rather than relying on the oxygen-limiting strategy alone. The emission of $\mathrm{N}_{2} \mathrm{O}$ from immobilized cell nitritation reactors should be evaluated for each type of the approach. The variation in nitritation performance, when organic matter is present in cell immobilization reactors, is still uncleared. All these points require further understanding in order to be addressed.

\section{Acknowledgment}

This work has been supported by the Research Network NANOTEC (RNN) program of the National Nanotechnology Center (NANOTEC), NSTDA, Ministry of Science and Technology, Thailand. Any opinions or recommendations expressed in this work are from the authors and do not necessarily reflect the views of the grant agency.

\section{Author Contributions}

P.K. (Ph.D. student) collected data and wrote the manuscript. P.N. (Master student) checked data. C.R. (Assistant professor) and T.L (Associated professor) outlined, wrote and revised the manuscript.

\section{References}

1. Van Hulle SWH, Vandeweyer HJP, Meesschaert BD, Vanrolleghem PA, Dejans P, Dumoulin A. Engineering aspects and practical application of autotrophic nitrogen removal from nitrogen rich streams. Chem. Eng. J. 2010;162:1-20.

2. Anthonisen AC, Loehr RC, Prakasam TBS, Srinath EG. Inhibition of Nitrification by Ammonia and Nitrous Acid. J. Water. Pollut. Control. Fed. 1976;48:835-852.

3. Hellinga C, Schellen AAJC, Mulder JW, Van Loosdrecht MCM, Heijnen JJ. The sharon process: An innovative method for nitrogen removal from ammonium-rich waste water. Water. Sci. Technol. 1998;37:135-142.

4. Ciudad G, Werner A, Bornhardt C, Muñoz C, Antileo C. Differential kinetics of ammonia- and nitrite-oxidizing bacteria: A simple kinetic study based on oxygen affinity and proton release during nitrification. Process. Biochem. 2006;41:1764-1772.

5. Sinha B, Annachhatre AP. Partial nitrification-operational parameters and microorganisms involved. Rev. Environ. Sci. Biotechnol. 2006;6:285-313.

6. Blackburne R, Yuan Z, Keller J. Partial nitrification to nitrite using low dissolved oxygen concentration as the main selection factor. Biodegradation 2008;19:303-312. 
7. Zheng $\mathrm{M}$, Liu YC, Xu KN, et al. Use of low frequency and density ultrasound to stimulate partial nitrification and simultaneous nitrification and denitrification. Bioresour. Technol. 2013;146:537-542.

8. Zheng M, Liu YC, Xin J, Zuo H, Wang CW, Wu WM. Ultrasonic treatment enhanced ammonia-oxidizing bacterial (AOB) activity for nitritation process. Environ. Sci. Technol. 2016;50: 864-871.

9. Hill CB, Khan EA. Comparative study of immobilized nitrifying and co-immobilized nitrifying and denitrifying bacteria for ammonia removal from sludge digester supernatant. Water. Air. Soil. Pollut. 2008;195:23-33.

10. Rongsayamanont C, Limpiyakorn T, Law B, Khan E. Relationship between respirometric activity and community of entrapped nitrifying bacteria: Implications for partial nitrification. Enzyme. Microb. Technol. 2010;46:229-236.

11. Rongsayamanont C, Limpiyakorn T, Khan E. Effects of inoculum type and bulk dissolved oxygen concentration on achieving partial nitrification by entrapped-cell-based reactors. Bioresour. Technol. 2014;164:254-263.

12. Jeong D, Cho K, Lee C-H, Lee S, Bae H. Integration of forward osmosis process and a continuous airlift nitrifying bioreactor containing PVA/alginate-immobilized cells. Chem. Eng. J. 2016;306:1212-1222.

13. Rathnayake RM, Song Y, Tumendelger A, et al. Source identification of nitrous oxide on autotrophic partial nitrification in a granular sludge reactor. Water Res. 2013;47:7078-7086.

14. Song Y, Ishii S, Rathnayake L, Ito T, Satoh H, Okabe S. Development and characterization of the partial nitrification aerobic granules in a sequencing batch airlift reactor. Bioresour. Technol. 2013;139:285-291.

15. Kunapongkiti P, Limpiyakorn T, Sonthiphand P, Rongsayamanont C. Partial nitrification in entrapped-cell-based reactors with two different cell-to-matrix ratios: Performance, microenvironment and microbial community. J. Environ. Sci. Health. A. 2019;54:874-883.

16. Koops HP, Purkhold U, Pommerening-Röser A, Timmermann G, Wagner M. The lithoautotrophic ammonia-oxidizing bacteria. In: Dworkin M. et al., eds. The prokaryotes: An evolving electronic resource for the microbiological community. New York: Springer-Verlag; release 3.13, March 2003.

17. Limpiyakorn T, Shinohara Y, Kurisu F, Yagi O. Communities of ammonia-oxidizing bacteria in activated sludge of various sewage treatment plants in Tokyo. FEMS Microbiol. Ecol. 2005;54:205-217.

18. Francis CA, Roberts KJ, Beman JM, Santoro AE, Oakley BB. Ubiquity and diversity of ammonia-oxidizing archaea in water columns and sediments of the ocean. Proc. Natl. Acad. Sci. USA. 2005;102:14683-14688.

19. Könneke M, Bernhard AE, De La Torre JR, Walker CB, Waterbury JB, Stahl DA. Isolation of an autotrophic ammonia-oxidizing marine archaeon. Nature 2005;437:543-546.

20. Brochier-Armanet C, Boussau B, Gribaldo S, Forterre P. Mesophilic crenarchaeota: Proposal for a third archaeal phylum, the Thaumarchaeota. Nat. Rev. Microbiol. 2008;6:245-252.

21. Limpiyakorn T, Sonthiphand P, Rongsayamanont C, Polprasert C. Abundance of amoA genes of ammonia-oxidizing archaea and bacteria in activated sludge of full-scale wastewater treatment plants. Bioresour. Technol. 2011;102:3694-3701.

22. Sinthusith N, Terada A, Hahn M, Noophan P, Munakata-Marr J, Figueroa LA. Identification and quantification of bacteria and archaea responsible for ammonia oxidation in different activated sludge of full-scale wastewater treatment plants. J. Environ. Sci. Health. A. 2015;50:169-175.

23. Gao J-F, Luo X, Wu G-X, Li T, Peng Y-Z. Quantitative analyses of the composition and abundance of ammonia-oxidizing archaea and ammonia-oxidizing bacteria in eight full-scale biological wastewater treatment plants. Bioresour. Technol. 2013;138:285-296.

24. Gao J, Luo X, Wu G, Li T, Peng Y. Abundance and diversity based on amoA genes of ammonia-oxidizing archaea and bacteria in ten wastewater treatment systems. Appl. Microbiol. Biotechnol. 2014;98:3339-3354.

25. Schramm A, De Beer D, Van Den Heuvel JC, Ottengraf S, Amann R. Microscale distribution of populations and activities of Nitrosospira and Nitrospira spp. along a macroscale gradient in a nitrifying bioreactor: Quantification by in situ hybridization and the use of microsensors. Appl. Environ. Microbiol. 1999;65:3690-3696.

26. Daims H, Nielsen JL, Nielsen PH, Schleifer KH, Wagner M. In situ characterization of Nitrospira-like nitrite-oxidizing bacteria active in wastewater treatment plants. Appl. Environ. Microbiol. 2001;67:5273-5284.

27. Lücker S, Schwarz J, Gruber-Dorninger C, Spieck E, Wagner M, Daims H. Nitrotoga-like bacteria are previously unrecognized key nitrite oxidizers in full-scale wastewater treatment plants. ISME J. 2015;9:708-720.

28. Nowka B, Daims H, Spieck E. Comparison of oxidation kinetics of nitrite-oxidizing bacteria: Nitrite availability as a key factor in niche differentiation. Appl. Environ. Microbiol. 2015;81: 745-753.

29. Daims H, Lebedeva EV, Pjevac P, et al. Complete nitrification by Nitrospira bacteria. Nature 2015;528:504-509.

30. Van Kessel MAHJ, Speth DR, Albertsen M, et al. Complete nitrification by a single microorganism. Nature 2015;528: 555-559.

31. Palomo A, Jane Fowler S, Gülay A, Rasmussen S, Sicheritz-Ponten T, Smets BF. Metagenomic analysis of rapid gravity sand filter microbial communities suggests novel physiology of Nitrospira spp. ISME J. 2016;10:2569-2581.

32. Pinto AJ, Marcus DN, Ijaz UZ, Santos QMBL, Dick GJ, Raskin L. Metagenomic evidence for the presence of comammox Nitrospira-like bacteria in a drinking water system. mSphere. 2016;1:e00054-15.

33. Roots P, Wang Y, Rosenthal AF, et al. Comammox Nitrospira are the dominant ammonia oxidizers in a mainstream low dissolved oxygen nitrification reactor. Water. Res. 2019;157: 396-405.

34. Peng Y, Zhu G. Biological nitrogen removal with nitrification and denitrification via nitrite pathway. Appl. Microbiol. Biotechnol. 2006;73:15-26.

35. Soliman M, Eldyasti A. Ammonia-oxidizing bacteria (AOB): Opportunities and applications-a review. Rev. Environ. Sci. Biotechnol. 2018;17:285-321. 
36. Cao Y, van Loosdrecht MCM, Daigger GT. Mainstream partial nitritation-anammox in municipal wastewater treatment: Status, bottlenecks, and further studies. Appl. Microbiol. Biotechnol. 2017;101:1365-1383.

37. Bae W, Baek S, Chung J, Lee Y. Optimal operational factors for nitrite accumulation in batch reactors. Biodegradation 2001;12:359-366.

38. Wang Q, Ye L, Jiang G, Hu S, Yuan Z. Side-stream sludge treatment using free nitrous acid selectively eliminates nitrite oxidizing bacteria and achieves the nitrite pathway. Water Res. 2014;55:245-255.

39. Xu G, Zhou Y, Yang Q, et al. The challenges of mainstream deammonification process for municipal used water treatment Appl. Microbiol. Biotechnol. 2015;99:2485-2490.

40. Desloover J, De Clippeleir H, Boeckx P, et al. Floc-based sequential partial nitritation and anammox at full scale with contrasting N2O emissions. Water Res. 2011;45:2811-2821.

41. Hanaki K, Wantawin C, Ohgaki S. Nitrification at low levels of dissolved oxygen with and without organic loading in a suspended-growth reactor. Water Res. 1990;24:297-302.

42. Liu W, Chen W, Yang D, Shen Y. Functional and compositional characteristics of nitrifiers reveal the failure of achieving mainstream nitritation under limited oxygen or ammonia conditions. Bioresour. Technol. 2019;275:272-279.

43. Zhou X, Liu X, Huang S, Cui B, Liu Z, Yang Q. Total inorganic nitrogen removal during the partial/complete nitrification for treating domestic wastewater: Removal pathways and main influencing factors. Bioresour. Technol. 2018;256:285-294.

44. Wijffels RH. Characterization of immobilized cells; Introduction. In: Wijffels RH, ed. Immobilized cells. Germany: Springer-Verlag Berlin Heidelberg GmbH; 2001. p. 1-5.

45. Wang X-X, Fang F, Chen Y-P, Guo J-S, Li K, Wang $\mathrm{H} . \mathrm{N}_{2} \mathrm{O}$ micro-profiles in biofilm from a one-stage autotrophic nitrogen removal system by microelectrode. Chemosphere 2017;175:482-489.

46. Chung J, Bae W, Lee YW, Rittmann BE. Shortcut biological nitrogen removal in hybrid biofilm/suspended growth reactors. Process. Biochem. 2007;42:320-328.

47. Zhang X, Liang Y, Ma Y, Du J, Pang L, Zhang H. Ammonia removal and microbial characteristics of partial nitrification in biofilm and activated sludge treating low strength sewage at low temperature. Ecol. Eng. 2016;93:104-111.

48. Bian W, Zhang S, Zhang Y, et al. Achieving nitritation in a continuous moving bed biofilm reactor at different temperatures through ratio control. Bioresour. Technol. 2017;226:73-79.

49. Liang Y, Li D, Zeng H, Zhang C, Zhang J. Rapid start-up and microbial characteristics of partial nitrification granular sludge treating domestic sewage at room temperature. Bioresour. Technol. 2015;196:741-745.

50. Yan J, Hu YY. Partial nitrification to nitrite for treating ammonium-rich organic wastewater by immobilized biomass system. Bioresour. Technol. 2009;100:2341-2347.

51. Chou WP, Tseng SK, Ho CM, Wu ZZ, Feng YJ, Hsia TH. Highly efficient partial nitrification by polyvinyl alcohol-alginate immobilized cells. J. Chin. Inst. Eng. 2012;35:793-801.

52. Isaka K, Sumino T, Tsuneda S. Novel nitritation process using heat-shocked nitrifying bacteria entrapped in gel carriers. Process. Biochem. 2008;43:265-270.
53. Rathnayake RMLD, Oshiki M, Ishii S, Segawa T, Satoh H, Okabe S. Effects of dissolved oxygen and $\mathrm{pH}$ on nitrous oxide production rates in autotrophic partial nitrification granules Bioresour. Technol. 2015;197:15-22.

54. Wijffels RH. Diffusion limitation. In: Wijffels RH, ed. Immobilized cells. Germany: Springer-Verlag Berlin Heidelberg $\mathrm{GmbH}$; 2001. p. 77-84.

55. Wijffels, RH. Biomass gradients. In: Wijffels RH, ed. Immobilized cells. Germany: Springer-Verlag Berlin Heidelberg $\mathrm{GmbH}$ 2001. p. 101-122.

56. Juhler S, Revsbech NP, Schramm A, Herrmann M, Ottosen LDM, Nielsen LP. Distribution and rate of microbial processes in an ammonia-loaded air filter biofilm. Appl. Environ. Microbiol. 2009;75:3705-3713.

57. Okabe S, Satoh H, Watanabe Y. In situ analysis of nitrifying biofilms as determined by in situ hybridization and the use of microelectrodes. Appl. Environ. Microbiol. 1999;65: 3182-3191

58. Ge S, Wang S, Yang X, Qiu S, Li B, Peng Y. Detection of nitrifiers and evaluation of partial nitrification for wastewater treatment: A review. Chemosphere 2015;140:85-98.

59. Miao L, Yang G, Tao T, Peng Y. Recent advances in nitrogen removal from landfill leachate using biological treatments-A review. J. Environ. Manage. 2019;235:178-185.

60. Jiang $\mathrm{C}, \mathrm{Xu} \mathrm{S}$, Wang $\mathrm{R}$, et al. Achieving efficient nitrogen removal from real sewage via nitrite pathway in a continuous nitrogen removal process by combining free nitrous acid sludge treatment and DO control. Water Res. 2019;161:590-600.

61. Gu J, Yang Q, Liu Y. A novel strategy towards sustainable and stable nitritation-denitritation in an A-B process for mainstream municipal wastewater treatment. Chemosphere 2018;193:921-927.

62. Lotti T, Kleerebezem R, Hu Z, et al. Pilot-scale evaluation of anammox-based mainstream nitrogen removal from municipal wastewater. Environ. Technol. 2015;36:1167-1177.

63. Liu T, Hu S, Guo J. Enhancing mainstream nitrogen removal by employing nitrate/nitrite-dependent anaerobic methane oxidation processes. Crit. rev. biotechnol. 2019;39:732-745.

64. Miao Y, Zhang L, Li B, Zhang Q, Wang S, Peng Y. Enhancing ammonium oxidizing bacteria activity was key to single-stage partial nitrification-anammox system treating low-strength sewage under intermittent aeration condition. Bioresour. Technol. 2017;231:36-44.

65. Zeng T, Li D, Jiang X, Qiu WX, Chen Q, Zhang J. Microbial characteristics of an ANAMMOX biofilter for sewage treatment. J. Water Process. Eng. 2016;12:105-110.

66. Tao C, Hamouda MA. Steady-state modeling and evaluation of partial nitrification-anammox (PNA) for moving bed biofilm reactor and integrated fixed-film activated sludge processes treating municipal wastewater. J. Water Process. Eng. 2019;31:100854.

67. Liu T, Ma B, Chen X, Ni BJ, Peng Y, Guo J. Evaluation of mainstream nitrogen removal by simultaneous partial nitrification, anammox and denitrification (SNAD) process in a granule-based reactor. Chem. Eng. J. 2017;327:973-981.

68. Seuntjens D, Han M, Kerckhof F-M, et al. Pinpointing wastewater and process parameters controlling the AOB to NOB 
activity ratio in sewage treatment plants. Water Res. 2018;138:37-46.

69. Zheng M, Wu S, Zuo Z, et al. Predictions of the influent and operational conditions for partial nitritation with a model incorporating pH dynamics. Environ. Sci. Technol. 2018:52: 6457-6465.

70. Soler-Jofra A, Wang R, Kleerebezem R, van Loosdrecht MCM, Pérez J. Stratification of nitrifier guilds in granular sludge in relation to nitritation. Water Res. 2019;148:479-491.

71. Val del Rio A, Campos JL, Da Silva C, Pedrouso A, Mosquera-Corral A. Determination of the intrinsic kinetic parameters of ammonia-oxidizing and nitrite-oxidizing bacteria in granular and flocculent sludge. Sep. Purif. Technol. 2019;213:571-577.

72. Lücker S, Wagner M, Maixner F, et al. A Nitrospira metagenome illuminates the physiology and evolution of globally important nitrite-oxidizing bacteria. Proc. Natl. Acad. Sci. USA. 2010;107:13479-13484.

73. Regmi P, Miller MW, Holgate B, et al. Control of aeration, aerobic SRT and COD input for mainstream nitritation/ denitritation. Water Res. 2014;57:162-171.

74. Pérez J, Costa E, Kreft JU. Conditions for partial nitrification in biofilm reactors and a kinetic explanation. Biotechnol. Bioeng. 2009;103:282-295.

75. Reino C, Suárez-Ojeda ME, Pérez J, Carrera J. Kinetic and microbiological characterization of aerobic granules performing partial nitritation of a low-strength wastewater at $10^{\circ} \mathrm{C}$. Water Res. 2016;101:147-156.

76. Blackburne R, Vadivelu VM, Yuan Z, Keller J. Kinetic characterisation of an enriched Nitrospira culture with comparison to Nitrobacter. Water Res. 2007;41:3033-3042.

77. Huang Z, Gedalanga PB, Asvapathanagul P, Olson BH. Influence of physicochemical and operational parameters on Nitrobacter and Nitrospira communities in an aerobic activated sludge bioreactor. Water Res. 2010;44:4351-4358.

78. Park HD, Noguera DR. Nitrospira community composition in nitrifying reactors operated with two different dissolved oxygen levels. J. Microbiol. Biotechnol. 2008;18:1470-1474.

79. Picioreanu C, Pérez J, van Loosdrecht MCM. Impact of cell cluster size on apparent half-saturation coefficients for oxygen in nitrifying sludge and biofilms. Water Res. 2016;106:371-382.

80. Isanta E, Reino C, Carrera J, Pérez J. Stable partial nitritation for low-strength wastewater at low temperature in an aerobic granular reactor. Water Res. 2015;80:149-158.

81. Poot V, Hoekstra M, Geleijnse MAA, van Loosdrecht MCM, Pérez J. Effects of the residual ammonium concentration on NOB repression during partial nitritation with granular sludge. Water Res. 2016;106:518-530.

82. Wang D, Wang Q, Laloo A, Xu Y, Bond PL, Yuan Z. Achieving stable nitritation for mainstream deammonification by combining free nitrous acid-based sludge treatment and oxygen limitation. Sci. Rep. 2016;6:25547.

83. Terada A, Sugawara S, Hojo K, et al. Hybrid nitrous oxide production from a partial nitrifying bioreactor: Hydroxylamine interactions with nitrite. Environ. Sci. Technol. 2017;51: 2748-2756.

84. Kampschreur MJ, Tan NCG, Kleerebezem R, Picioreanu C,
Jetten MSM, Van Loosdrecht MCM. Effect of dynamic process conditions on nitrogen oxides emission from a nitrifying culture. Environ. Sci. Technol. 2008;42:429-435.

85. Ahn JH, Kwan T, Chandran K. Comparison of partial and full nitrification processes applied for treating high-strength nitrogen wastewaters: Microbial ecology through nitrous oxide production. Environ. Sci. Technol. 2011;45:2734-2740.

86. Peng L, Ni BJ, Erler D, Ye L, Yuan Z. The effect of dissolved oxygen on $\mathrm{N} 2 \mathrm{O}$ production by ammonia-oxidizing bacteria in an enriched nitrifying sludge. Water Res. 2014;66:12-21.

87. Ni BJ, Yuan Z. Recent advances in mathematical modeling of nitrous oxides emissions from wastewater treatment processes. Water Res. 2015;87:336-346.

88. Schreiber F, Loeffler B, Polerecky L, Kuypers MM, de Beer D. Mechanisms of transient nitric oxide and nitrous oxide production in a complex biofilm. ISME J. 2009;3:1301-1313.

89. Wan X, Baeten JE, Volcke EIP. Effect of operating conditions on $\mathrm{N}_{2} \mathrm{O}$ emissions from one-stage partial nitritation-anammox reactors. Biochem. Eng. J. 2019;143:24-33.

90. Jia M, Castro-Barros CM, Winkler MKH, Volcke EIP. Effect of organic matter on the performance and N2O emission of a granular sludge anammox reactor. Environ. Sci.: Water. Res. Technol. 2018;4:1035-1046.

91. Peng L, Ni BJ, Ye L, Yuan Z. The combined effect of dissolved oxygen and nitrite on $\mathrm{N} 2 \mathrm{O}$ production by ammonia oxidizing bacteria in an enriched nitrifying sludge. Water Res. 2015;73:29-36.

92. Xu H, Wang C, Liang Z, He L, Wu W. The structure and component characteristics of partial nitrification biofilms under autotrophic and heterotrophic conditions. Appl. Microbiol. Biotechnol. 2015;99:3673-3683.

93. Rodriguez-Sanchez A, Mikola A, Muñoz-Palazon B, Vahala R, Gonzalez-Martinez A. Performance and bacterial community structure of a submerged biofilter subjected to high ammonium and high organic carbon concentrations. Int. Biodeterior. Biodegradation. 2016;115:224-233.

94. Jimenez J, Miller M, Bott C, Murthy S, De Clippeleir H, Wett B. High-rate activated sludge system for carbon management-Evaluation of crucial process mechanisms and design parameters. Water Res. 2015;87:476-482.

95. Diamantis V, Verstraete W, Eftaxias A, et al. Sewage pre-concentration for maximum recovery and reuse at decentralized level. Water Sci. Technol. 2013;67:1188-1193.

96. Delgado Vela J, Stadler LB, Martin KJ, Raskin L, Bott CB, Love NG. Prospects for biological nitrogen removal from anaerobic effluents during mainstream wastewater treatment. Environ. Sci. Technol. Lett. 2015;2:234-244.

97. Wang J, Zhang Z, Qian F, et al. Rapid start-up of a nitritation granular reactor using activated sludge as inoculum at the influent organics/ammonium mass ratio of $2 / 1$. Bioresour. Technol. 2018;256:170-177.

98. Thamdrup B. New pathways and processes in the global nitrogen cycle. Annu. Rev. Ecol. Evol. Syst. 2012;43:407-428.

99. Ruiz G, Jeison D, Chamy R. Nitrification with high nitrite accumulation for the treatment of wastewater with high ammonia concentration. Water Res. 2003;37:1371-1377.

100. Ciudad G, Rubilar O, Muñoz P, et al. Partial nitrification 
of high ammonia concentration wastewater as a part of a shortcut biological nitrogen removal process. Process. Biochem. 2005;40:1715-1719.

101. Rajagopal R, Béline F. Nitrogen removal via nitrite pathway and the related nitrous oxide emission during piggery wastewater treatment. Bioresour. Technol. 2011;102:4042-4046.

102. Bao P, Wang S, Ma B, Zhang Q, Peng Y. Achieving partial nitrification by inhibiting the activity of Nitrospira-like bacteria under high-DO conditions in an intermittent aeration reactor. J. Environ. Sci. 2017;56:71-78.

103. Vázquez-Padín JR, Figueroa M, Campos JL, Mosquera-Corral A, Méndez R. Nitrifying granular systems: A suitable technology to obtain stable partial nitrification at room temperature. Sep. Purif. Technol. 2010;74:178-186.

104. Liang Z, Han Z, Yang S, et al. A control strategy of partial nitritation in a fixed bed bioflim reactor. Bioresour. Technol. 2011;102:710-715. 